\title{
The relationship between hygienic behavior and suppression of mite reproduction as honey bee (Apis mellifera) mechanisms of resistance to Varroa destructor ${ }^{1}$
}

\author{
Abdullah IBRAHIM, Marla SPIVAK* \\ Department of Entomology, University of Minnesota 219 Hodson Hall, 1980 Folwell Av., St. Paul, \\ MN 55108, USA
}

Received 4 April 2005 - revised 3 June 2005 - accepted 22 June 2005

\begin{abstract}
We compared the mechanisms of resistance to Varroa destructor displayed by bees bred for Suppression of Mite Reproduction (SMR) and hygienic behavior (HYG). Mites from SMR and HYG source colonies were introduced into recently sealed SMR and HYG worker brood, and the infested pupae were placed either into recipient colonies or into an incubator. SMR colonies removed significantly more miteinfested pupae than the HYG colonies. The reproductive success (fertility and number of viable female offspring) of mites from both sources on pupae not removed by bees was significantly lower in SMR colonies. Within the incubator, the reproductive success of mites was also lower on SMR worker pupae, and lowest when mites from SMR colonies were introduced on SMR brood. Our findings indicated that bees bred for SMR express hygienic behavior; adult bees selectively remove pupae infested with mites. In addition, there is an effect of SMR pupae that reduces mite reproductive success that requires further investigation.
\end{abstract}

Apis mellifera / suppression of mite reproduction / hygienic behavior / Varroa destructor

\section{INTRODUCTION}

The parasitic mite, Varroa destructor Anderson and Truman is a serious pest of honey bee colonies derived from European subspecies of Apis mellifera L. The application of pesticide treatments in bee colonies has led to the development of resistance by the mites (reviewed in Milani, 1999), and the propagation of susceptible colonies by beekeepers. A more sustainable solution to the mite problem is to select lines of honey bees that show natural mechanisms of resistance to the mite.

Harbo and Hoopingarner (1997) bred a line of bees that maintained low mite levels because the mites appeared to have low reproductive success on worker brood. They found the trait to be a heritable trait of the bees, and called it
Suppression of Mite Reproduction (SMR). In colonies bred for SMR, the mites entered worker brood cells to feed and reproduce; however, the authors reported that the mites died in the cell without reproducing, produced no progeny, produced males only, or produced progeny too late to mature (Harbo and Harris, 1999). The mechanism for how the bees could suppress mite reproduction in these ways was not known (Harris and Harbo, 1999).

Another factor that hinders mite reproduction is hygienic behavior. Hygienic behavior is considered the primary mechanism of honey bee resistance to two diseases of brood, American foulbrood (caused by the bacteria, Paenibacillus larvae subsp. larvae; Rothenbuhler, 1964; Spivak and Reuter, 2001a) and chalkbrood (caused by the fungus, Ascosphaera apis;

\footnotetext{
* Corresponding author: spiva001@umn.edu

${ }^{1}$ Manuscript editor: Gudrun Koeniger
} 
Gilliam et al., 1983, 1988), and is one of various mechanisms of resistance against $V$. destructor (reviewed in Boecking and Spivak, 1999). Bees bred for hygienic behavior detect, uncap, and remove diseased brood from the colony before the disease reaches the infectious stage (Park, 1937; Woodrow and Holst, 1942; Rothenbuhler, 1964). Bees bred for hygienic behavior also detect and remove mite-infested pupae from the colony (Spivak, 1996). In contrast to the removal of diseased infested brood which must be done before or during the 5th larval instar to avoid handling and transmitting disease spores, hygienic bees removed the majority of miteinfested brood at least 60 hours after the cell is sealed, which is after the mite has initiated oviposition (Donzé et al., 1996), when the bee is in the pupal stage (Spivak, 1996). Removing the pupa at that time ensures destruction of any mite progeny. Extensive field studies carried out by Spivak and Reuter (1998a, 2001b) showed that the colonies bred for hygienic behavior produced as much honey as unselected control colonies and had lower levels of mites than the control colonies, but the degree of removal of infested pupae by hygienic behavior was not sufficient to maintain the mite population below an estimated economic threshold (Delaplane and Hood, 1999).

The aim of our study was to determine how bees from the SMR line suppressed mite reproduction. During the course of other experiments also involving the SMR line, we conducted a standard freeze-killed brood assay for hygienic behavior (Spivak and Reuter, 1998b) on some colonies containing queens bred for SMR obtained from J. Harbo. We found that SMR colonies removed $98.6 \%$ ( \pm 0.9 s.d., $n=7$ colonies) of the freeze-killed brood within 48 hours, which indicated that they were expressing hygienic behavior. These results were surprising because J. Harbo selectively bred only for reduced mite reproduction, not for hygienic behavior (Harbo and Harris, 1999). Based on these findings, and our previous data (Spivak, 1996) which suggest that the bees detect the majority of mite-infested pupae only after the mite has initiated oviposition, we hypothesized that the SMR bees could be detecting and removing pupae on which the mites were reproducing, leaving mites that did not reproduce successfully. If so, the assay for SMR, which involves inspecting mite reproductive success on late stage pupae (Harbo and Harris, 1999) would reveal pupae with mites that did not reproduce successfully because the majority of the others would have been removed previously by the bees. We used mite fertility and the number of viable female offspring, NVO, as two measures of reproductive success. Fertility is defined as the number of foundress mites that produced at least one male offspring (e.g., Mondragon et al., 2005). NVO is defined more specifically by the presence of at least one live adult daughter mite and one live adult male when the bee pupa is in the gray wing-pad stage, at least $230 \mathrm{~h}$ or approximately 10 days postcapping (Medina and Martin, 1999; CorrêaMarques et al., 2003). At this stage of development of the bee pupa, there is a high probability that the adult daughter would have been mated by the male (Donzé et al., 1996), and so can be considered a viable female offspring.

The removal of mite-infested pupae is an effect of adult bee behavior. We also wanted to investigate the possibility that there could be a brood effect; i.e., there might be some physiological factor associated with SMR worker brood that somehow reduces the reproductive success of mites. Therefore, our experiments were designed to answer three questions; the first two concerned the extent of the adult bee effect on mite reproduction, and the third on the possible brood effect.

1. Do bees bred for Suppression of Mite Reproduction (SMR) detect and remove mite-infested pupae?

2. If so, do SMR bees preferentially remove pupae infested with mites with high reproductive success leaving pupae with mites with low reproductive success?

3. What is the reproductive success of mites from SMR colonies when bees are not allowed to remove mite-infested brood?

\section{MATERIALS AND METHODS}

\subsection{Lines of bees}

The experiments were conducted on the St Paul campus of the University of Minnesota in the summer of 2004. The breeding program for hygienic behavior was established in 1993 at the University of Minnesota by selecting colonies of Italian derived A. mellifera bees using a freeze-killed brood assay (Spivak and Downey, 1998; Spivak and Reuter, 
1998b). Colonies that uncapped and removed $95 \%$ freeze-killed brood within $48 \mathrm{~h}$ were considered hygienic. To establish and maintain the hygienic lines, we raised daughter queens from colonies that displayed the most rapid removal rates. For each generation, the daughter hygienic queens were instrumentally inseminated with a mixture of semen collected from drones from different hygienic colonies (Spivak and Gilliam, 1998).

J. Harbo provided us with the instrumentally inseminated queens from the SMR line. To breed this line, Harbo and Hoopingarner (1997) began selecting honey bees colonies for resistance to $V$. destructor by measuring several characteristics that impeded the growth of mite populations in bee colonies, such as hygienic behavior, grooming behavior, short post capping period, and the frequency of non-reproducing mites. Of 43 colonies, only three had fewer mites than at the beginning of the test, and only "non-reproduction" (defined as mites that enter the cell to reproduce but produce no progeny, produce males only, produce progeny too late to mature, or die in the cell before they can produce) was correlated with changes in mite population (Harbo and Harris, 1999). Daughter queens were instrumentally inseminated with semen from single drones to propagate a line of bees that suppressed mite reproduction.

\subsection{Mite source}

All mites used in the experiments were collected from one hygienic and one SMR colony to control for variability in reproductive success of the mites due to colony rearing environment. Previous research (Harbo and Harris, 1999) demonstrated that the reproductive success of mites within SMR colonies is not suppressed until after one reproductive cycle, a phenomenon they termed "Delayed Suppression of Mite Reproduction." Therefore, the mites we collected from the SMR mite-source colony had been present for at least one month before the experiments began. The use of mites from a hygienic colony served as a control because our preliminary research (Ibrahim and Spivak, 2004 and unpublished data) showed that the reproductive success of individual mites in worker brood within hygienic colonies is the same as the success of mites in unselected colonies over time.

\subsection{Experimental methods}

Question 1: We tested whether colonies from the Hygienic line (HYG) and from the SMR line preferentially removed mites that have developed within their own line or the other line of bees. The methods of Boecking (1992), and Spivak (1996) were used to obtain mite-infested brood. Female mites were dislodged from adult bees of the two mite-source col- onies, one SMR and one HYG, by dusting about 3000 bees in powdered sugar (Macedo and Ellis, 2002). In the lab, mites from both mite source colonies were introduced into cells containing recently sealed 5th instar larvae within the recipient three SMR and three HYG colonies, so that each recipient colony received 80 mites, 40 from each mite source. The larvae to be infested were obtained by marking unsealed 5th instars on a plastic transparency, and four hours later, introducing mites into only those that had been sealed in the interim. The mites were introduced by making a small opening in the edge of each cell's wax capping using a sharp forceps, introducing the mite through the opening with a fine paintbrush, and then carefully resealing the cell. An additional set of cells containing recently sealed 5 th instars were opened and resealed, without introducing a mite, to serve as controls for the cell manipulation. Each location of mite-treated and control cell was marked on a plastic transparency, and the frames of brood containing the treated cells were returned to the original recipient colonies. Every two days for 10 days, the number of mite-infested and control cells removed by the bees were recorded.

Question 2: To test whether SMR bees preferentially remove pupae infested with mites with high reproductive success, leaving pupae with mites with low reproductive success, we recorded fertility and the number of viable female offspring of the mites on pupae that were not removed by the bees within the three SMR and three HYG colonies from Question 1. On day 10 after the brood was sealed, remaining pupae in the gray wing-pad stage were inspected for the presence of mites and their progeny under a dissecting microscope. The pupae from each cell were removed into a petri dish and each was examined for the presence of the mother mite, a male, and the different life stages of its offspring following the ontogenetic developmental chart in Martin (1994). Mite fertility was calculated for each colony by dividing the number of reproductive foundresses (mites that produced at least one male offspring) by the number of introduced mites that remained on pupae. Number of viable offspring was determined by dividing the total number of adult female daughters by the total number of remaining mites (including reproductive and non reproductive foundress). Adult daughters can be recognized by the presence of a live, adult male and the presence of a female with a shed exuvia of the final molt, or if the exuvia could not be found, by light dark brownish color of the mite's body.

Question 3: In this experiment, we wanted to eliminate the effect of adult bee removal behavior on mite-reproductive success. Mites were collected and manually introduced into brood cells, as described above in Question 1. The frames containing the infested cells were placed in an incubator held at hive 


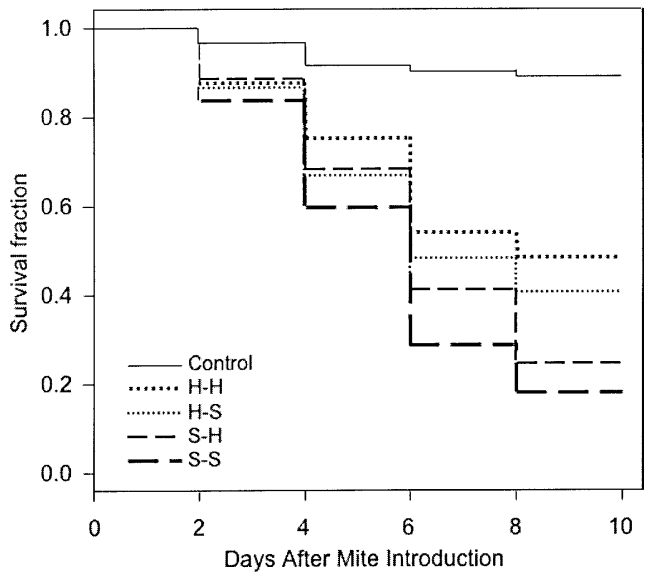

Figure 1. Survival curve showing the proportion of mite-infested pupae surviving (i.e., not removed by bees) every two days from the day the mites were introduced (within $4 \mathrm{~h}$ of the cell being capped with wax by the bees) to day 10 post-capping within 3 HYG and 3 SMR colonies. Control cells (pooled among all colonies) refer to cells containing recently sealed larvae that were sham-manipulated; the cell was opened and resealed without introducing a mite. $\mathrm{H}-\mathrm{H}=\mathrm{HYG}$ bee colonies-HYG mite-source colony; $\mathrm{H}-\mathrm{S}=\mathrm{HYG}$ bee colonies-SMR mitesource colony; $\mathrm{S}-\mathrm{H}=\mathrm{SMR}$ bee colonies-HYG mite source colonies; $\mathrm{S}-\mathrm{S}=\mathrm{SMR}$ bee colonies-SMR mite-source colonies.

temperature and humidity $\left(34{ }^{\circ} \mathrm{C}\right.$ and $\left.70 \% \mathrm{RH}\right)$. The two measures of reproductive success of the mites on grey wing-pad pupae were recorded on day 10 , after the brood cells were sealed, following the methods described above.

\subsection{Statistical analysis}

Question 1. The proportion of mites (from both mite sources) removed by the SMR and HYG colonies of bees on days 2, 4, 6, 8 and 10 after mite introduction was analyzed by comparing Kaplan-Meier survivorship curves using the Survfit procedure from R statistical software.

Questions 2 and 3. Measures of mite fertility and the number of female offspring produced were compared using a non-linear mixed-model (Proc NLMixed, SAS version 8.2; see also, McCulloch and Searle, 2002), or log likelihood chi-square tests.

\section{RESULTS}

\subsection{Question 1}

By day 10 after mite introduction, the three SMR colonies removed $84.5 \% \pm 7.4$ of the pupae containing mites from the SMR mitesource colony, and $80.1 \% \pm 14.9$ of the pupae containing mites from the HYG mite-source colony. In contrast, the three HYG colonies removed $65.7 \% \pm 10.8$ of the pupae containing mites from the SMR mite-source colony and $61.7 \% \pm 7.3$ from the HYG mite-source colonies. Of the control cells (cells manipulated with no mite introduction) the SMR and HYG colonies removed pupae from $10.8 \% \pm 1.4$ and $12.4 \% \pm 0.7$ of the cells, respectively. Figure 1 shows the data as a survival function; i.e., the proportion of treated and pooled control pupae that survived (were not removed) at each time interval. A log rank test of the survival curves revealed a highly significant treatment effect $\left(\chi^{2}=395 ; \mathrm{df}=4, P<0.0001\right)$ between the survival of pupae within mite-infested vs. control cells. Subsequently, to determine if the source of mites affected the proportion of pupae that survived (were not removed) in each line, the control cells were excluded from the data set. There was no significant effect of mite source on the number of pupae removed by the bees $\left(\chi^{2}=2.9 ; \mathrm{df}=1, P=0.088\right)$. However, there was a highly significant effect of bee type: $\left(\chi^{2}=18.9 ; \mathrm{df}=1, P<0.0001\right)$; the SMR colonies removed significantly more infested pupae than the HYG colonies, irrespective of the source of the mites.

\subsection{Question 2}

The reproductive success of the mites on pupae that were not removed by the bees is shown in Table I. Within the three SMR colonies combined, only 43 of the 241 experimentally infested pupae remained, and upon inspection, mites were missing in $14(32.6 \%)$ of the pupal cells, and were found dead within in $2(4.6 \%)$ others. Of the 27 remaining pupae that contained live mites in the SMR colonies, 10 contained mites that did not oviposit, so the overall fertility (proportion of mites that produced at least one egg) was 63\%. However, only 1 mite produced a viable female offspring that would have mated with the male in the cell, resulting in an overall proportion of viable female offspring produced in SMR colonies of only $3.7 \%$.

In contrast, 89 of 243 infested pupae remained within the HYG colonies, and mites were missing from 5 cells $(5.6 \%)$ or were found 
Table I. Number of mite-infested worker pupae that were not removed by bees, and the reproductive success of the surviving mites on the pupae. The data from the 3 SMR and $3 \mathrm{HYG}$ colonies are pooled, as there were no significant differences among them. See text for statistics.

\begin{tabular}{|c|c|c|c|c|}
\hline Line of bees & SMI & onies & HYC & onies \\
\hline Mite source & SMR & HYG & SMR & HYG \\
\hline Total pupae infested (approx 40 mites per 3 colonies) & 122 & 119 & 123 & 120 \\
\hline Pupae not removed by bees & 19 & 24 & 42 & 47 \\
\hline Mite missing on pupae ${ }^{1}$ & 7 & 7 & 3 & 2 \\
\hline Mite dead in cell & 0 & 2 & 2 & 0 \\
\hline Pupae remaining with live mites & 12 & 15 & 37 & 45 \\
\hline Mite alive, no offspring & 6 & 4 & 6 & 6 \\
\hline Mite + male only & 2 & 3 & 1 & 3 \\
\hline Mite + male + protonymph ${ }^{2}$ & 3 & 1 & 2 & 1 \\
\hline Mite + male + early deutonymph ${ }^{2}$ & 0 & 5 & 4 & 2 \\
\hline Mite + male + late deutonymph ${ }^{2}$ & 0 & 2 & 17 & 18 \\
\hline Mite + male + adult daughter ${ }^{2}$ & 1 & 0 & 7 & 15 \\
\hline Mite fertility (proportion of mites that oviposited) & 0.50 & 0.73 & 0.84 & 0.87 \\
\hline $\begin{array}{l}\text { Number of viable female offspring (proportion of adult } \\
\text { offspring/cell) }\end{array}$ & 0.08 & 0 & 0.19 & 0.33 \\
\hline
\end{tabular}

dead in 2 cells $(2.2 \%)$. Of the 82 remaining pupae containing live mites, $70(85.4 \%)$ of the mites were fertile, and $22(26.8 \%)$ produced at least one viable adult female offspring.

Because of the low number of infested pupae remaining within the SMR colonies, it was not possible to use a full statistical model with colonies as a random effect to examine measures of mite fertility or number of viable female offspring. Therefore, the data was pooled among colonies within each line and analyzed using log likelihood chi-square tests. Mites remaining within SMR colonies were significantly less fertile than mites within HYG colonies (effect of bee type: $\chi^{2}=6.00 ; \mathrm{df}=1, P=0.014$ ), irrespective of mite source (effect of mite source: $\chi^{2}=1.11$; df $\left.=1, P=0.293\right)$. Likewise, mites remaining on pupae within SMR colonies produced significantly fewer viable female offspring compared to mites within HYG colonies $\left(\chi^{2}=4.69 ; \mathrm{df}=1, P=0.030\right)$, irrespective of mite source $\left(\chi^{2}=1.31\right.$; $\mathrm{df}=1$, $P=0.252)$

\subsection{Question 3}

Table II shows results from when the experimentally infested pupae developed in an incubator, so that the bees could not interrupt the reproductive cycle of the mites. The larger sample sizes allowed us to use a non-linear mixed model (Proc NLMixed; SAS 8.2), to take into consideration the source of mites introduced onto the pupae within each line of bees as main effects with individual colonies as a random source of variation. There was no interaction between brood type (SMR or HYG pupae) and mite source, so the model was run excluding the interaction term. The mites were significantly less fertile on SMR brood than on HYG brood (NLMixed model: $\mathrm{t}=-2.44$; $\mathrm{df}=11 ; P=$ $0.033)$, irrespective of mite source $(\mathrm{t}=-0.27$; df $=11 ; P=0.795)$. A further comparison of the fertility of mites within SMR brood only, using a log likelihood chi-square test, indicated that mites collected from SMR colonies were significantly less fertile on their own pupae 
Table II. The reproductive success of the mites that developed on worker pupae within combs placed in an incubator $\left(34^{\circ} \mathrm{C}, 70 \% \mathrm{RH}\right)$. The data from the $3 \mathrm{SMR}$ and $3 \mathrm{HYG}$ colonies are pooled, as there were no significant differences among them. Explanation of categories for mite reproductive success as in Table I. See text for statistics.

\begin{tabular}{lcccc} 
Line of bees & \multicolumn{2}{c}{ SMR brood } & \multicolumn{2}{c}{ HYG brood } \\
\hline Mite source & SMR & HYG & SMR & HYG \\
\hline Total pupae infested (approx 40 mites per 3 colonies) & 118 & 120 & 120 & 120 \\
Mite missing on pupae & 4 & 6 & 5 & 2 \\
Mite dead in cell & 1 & 2 & 0 & 3 \\
Pupae remaining with live mites & 113 & 112 & 115 & 115 \\
Mite alive, no offspring & 47 & 32 & 26 & 26 \\
Mite + male only & 9 & 11 & 17 & 7 \\
Mite + male + protonymph & 12 & 6 & 18 & 3 \\
Mite + male + early deutonymph & 22 & 27 & 20 & 22 \\
Mite + male + late deutonymph & 22 & 32 & 22 & 43 \\
Mite + male + adult daughter & 1 & 4 & 12 & 14 \\
Mite fertility & 0.58 & 0.71 & 0.77 & 0.77 \\
Number of viable female offspring & 0.009 & 0.04 & 0.10 & 0.12
\end{tabular}

compared to mites collected from HYG colonies $\left(\chi^{2}=4.21 ; \mathrm{df}=1 ; P=0.040\right)$.

Mites within SMR brood produced significantly fewer viable female offspring compared to mites within HYG brood (NLMixed model: $\mathrm{t}=-2.56 ; \mathrm{df}=11 ; P=0.026)$ irrespective of mite source $(\mathrm{t}=-1.04 ; \mathrm{df}=11 ; P=0.322)$.

\section{DISCUSSION}

The results of this study confirmed our first hypothesis that bees in colonies bred for the trait Suppression of Mite Reproduction (SMR) are capable of detecting, uncapping, and removing mite-infested pupae from the cells. In fact, bees bred for SMR uncapped and removed significantly more infested pupae than bees bred for hygienic behavior (HYG). Our second hypothesis, that bees bred for SMR selectively remove pupae with mites that have high reproductive success, leaving pupae with mites that have low reproductive success at first appeared to be supported: the fertility and number of viable female offspring of mites on remaining pupae were significantly less within SMR colonies than within HYG colonies. However, the results of the incubator experiment showed that the second hypothesis was in fact not sup- ported: mites, irrespective of source colony, were significantly less fertile and produced significantly fewer viable female offspring on SMR brood than on HYG brood, which indicates that there is a separate effect of SMR worker brood on mite reproductive success in addition to the adult bee removal effect. If all mites have low reproductive success on SMR worker brood, adult SMR bees are probably not selectively detecting and removing pupae containing mites with relatively high reproductive success. SMR bees may be highly sensitive to the cue(s) associated with an infested pupa (e.g., mite offspring, mite feces, wounded pupa), and remove a high proportion of these pupae. The combination of SMR bees removing a high proportion of mite-infested pupae, and the low reproductive success of mites on SMR brood in general, could explain the low reproductive success of mites remaining on pupae within these colonies. Recent findings by Harbo and Harris (2005) using different methods, also confirmed that SMR colonies detected and removed mite-infested pupae, and the remaining pupae in cells with mites had low reproductive success. Although it is unlikely that SMR bees can selectively detect degrees of reproductive success of the mites on pupae, further studies could be conducted to clarify this question. 
The source of the introduced mites, whether collected from the SMR or HYG colony, did not have an effect on either line of bees' removal response or on the reproductive success of the mites on pupae that were not removed. However, within the incubator, mites from both sources were significantly less fertile on SMR brood than on HYG brood, and the lowest measures of reproductive success were recorded when mites from SMR colonies were introduced on SMR brood.

Although this study was based on a low number of colonies (three SMR and three HYG), and the mite source colonies were not replicated, our findings, together with those of Harbo and Harris (2005) provide strong evidence that colonies selected for Suppression of Mite Reproduction express hygienic behavior by detecting and removing mite-infested pupae. Our measures of mite fertility within hygienic colonies in the field (84-87\%) were comparable to those reported elsewhere for colonies that did not display hygienic behavior (e.g., $88 \%$ in Mondragon et al., 2005), supporting our use of hygienic colonies, and mites from hygienic colonies as controls. For unknown reasons, the fertility of mites was $10 \%$ lower in brood placed in the incubator compared to in field colonies. It is possible that the humidity level in the incubator, which is known to affect mite reproduction (Le Conte et al., 1990; Kraus and Velthuis, 1997), may have contributed to this difference.

The findings from the first question indicated that the main mechanism of the trait, Suppression of Mite Reproduction, is similar to, if not the same as, hygienic behavior. Adult bees from SMR colonies detect and remove miteinfested pupae. Bees bred for SMR appeared to be highly sensitive to the cues that elicit removal behavior and detected and removed more mite-infested pupae than did the HYG colonies. One possible explanation for the difference in effectiveness of mite removal by the two lines of bees could be due to the different assays used to select the lines for mite resistance. The line bred for hygienic behavior was selected based on colonies' removal of freezekilled brood; whereas, the line bred for SMR was selected based on the low number of mites remaining in cells just before worker pupae emerged. The freeze-killed brood assay has been used as an indirect correlate of actual hygienic behavior, which is the removal of dis- eased or mite infested brood. The results of the freeze-killed brood assay do not perfectly predict whether a colony will be resistant to disease (Gilliam et al., 1988; Spivak and Gilliam, 1993; Spivak and Reuter, 2001a) and bees bred for hygienic behavior based on this assay do not show complete resistance to $V$. destructor (Spivak and Reuter, 1998a, 2001b). Selection for colonies that had negative mite population growth after a certain period of time, as was done to select the SMR line, apparently put greater selection pressure on adult bees to detect and remove infested pupae. Therefore, in contrast to the indirect freeze-killed brood assay, the assay for SMR was direct, and the bees' response was quite specific; they were able to detect and remove more mite-infested pupae.

It is not clear whether HYG and SMR are controlled by the same genes. We speculate that the SMR bees have greater olfactory sensitivity to the cues associated with mite infested pupae, and respond to those cues with greater speed and acuity than do HYG bees. We base this speculation on our previous studies on the olfactory sensitivity and responsiveness of hygienic vs. non-hygienic bees to the odors of diseased brood (Masterman et al., 2001; Spivak et al., 2003). It would be interesting to test the olfactory sensitivity of bees bred for SMR using the same electroantennogram and proboscis-extension response conditioning assays used in these previous studies. It would also be interesting to test whether SMR colonies are resistant to the bacterial disease American foulbrood, and the fungal disease, chalkbrood and compare their removal response with colonies selected for HYG behavior based on the freezekilled assay. If SMR colonies are detect and remove a greater proportion of diseased brood, it would indicate the basic genetic and neurological mechanisms are the same between the HYG and SMR traits.

The results of our third question add new information to the recent study by Harbo and Harris (2005) and indicate that there may be genetic or environmentally induced differences between worker pupae from HYG and SMR colonies that influence mite reproductive success. Mites collected from HYG and SMR source colonies were less fertile and produced fewer viable female offspring on SMR pupae than on HYG pupae. This finding suggests that there may be a physiological effect of SMR 
worker pupae that reduces mite reproductive success. The mechanism for this effect of brood type on mite reproduction is unknown and remains to be investigated. It is possible that the same factor that hinders mite reproduction also affects the development and viability of the pupa itself, as some colonies bred for SMR have very low brood viability.

\section{ACKNOWLEDGEMENTS}

We thank Gary Reuter for his assistance with data collection, colony maintenance, and comments on original versions of the manuscript. Dr. Sanford Weisberg, School of Statistics, University of Minnesota and Dr. Matt Carroll provided statistical advice. The research was supported by North Central Sustainable Agriculture, Research and Education grant LNC02-202, and by beekeeping associations in MN, ND, SD, IA, and WI. Special thanks to the MN Honey Producers Association for their continued encouragement and support.

Résumé - Relation entre le comportement hygiénique et la suppression de la reproduction des acariens comme mécanisme de résistance des abeilles (Apis mellifera) à Varroa destructor. Nous avons étudié le mécanisme selon lequel des abeilles (Apis mellifera), sélectionnées pour le caractère «suppression de la reproduction des acariens » (abeilles SMR), pouvaient agir négativement sur le succès reproductif (S.R.) de l'acarien Varroa destructor, notre hypothèse étant que les abeilles SMR détectent et éliminent les nymphes qui ont des acariens reproducteurs, donnant ainsi l'impression que les acariens restant sur les nymphes au stade prééclosion se reproduisent mal. Nous avons utilisé la fertilité des acariens et le nombre de descendants femelles viables comme mesure du S.R. Nous avons aussi étudié s'il existe un facteur physiologique associé au couvain d'ouvrières SMR qui réduit le S.R. des acariens. Nous avons comparé des colonies sélectionnées pour le caractère SMR, fournies par Harbo, avec des colonies sélectionnées pour le comportement hygiénique (abeilles HYG) élevées à l'université du Minnesota. Pour tester si les abeilles SMR pouvaient détecter et éliminer les nymphes infestées, nous avons introduit des acariens des colonies sources SMR et HYG dans du couvain d'ouvrières SMR et $\mathrm{HYG}$ récemment operculé. Au $10^{\mathrm{e}}$ jour après l'introduction des acariens, les trois colonies SMR avaient éliminé significativement plus de nymphes infestées que les trois colonies HYG, quelle que fût la source des acariens $(P<$ 0,0001) (Fig. 1). Ensuite nous avons relevé le S.R. des acariens sur les nymphes restantes (Tab. I). Les acariens dans les colonies SMR étaient significativement moins fertiles (moins d'acariens ont pondu au moins un œuf) que ceux des colonies HYG $(P=$ $0,014)$. Ils ont aussi produit significativement moins de descendantes viables (définies par la présence d'un acarien adulte fille et d'un acarien adulte mâle sur une nymphe au stade du bourrelet alaire gris) que ceux des colonies HYG $(P=0,030)$. Pour étudier l'action du couvain SMR sur le S.R. des acariens, nous avons placé du couvain infesté dans une étuve réglée à la température et à l'hygrométrie de la ruche (Tab. II). Les acariens étaient significativement moins fertiles $(P=0,033)$ et ont produit significativement moins de descendantes viables $(P=0,026)$ sur le couvain SMR que sur le couvain HYG. Les résultats confirment donc notre hypothèse: les abeilles SMR détectent, désoperculent et éliminent significativement plus de nymphes infestées que les abeilles HYG. Il ne semble pas que les abeilles SMR éliminent sélectivement les nymphes avec acariens à S.R. élevé et laissent les nymphes avec acariens à S.R. faible, parce que l'étude en étuve a montré que tous les acariens avaient un S.R. plus faible sur le couvain SMR que sur le couvain HYG. En conséquence la combinaison des abeilles SMR, qui éliminent une forte proportion d'abeilles infestées, et le faible succès reproductif des acariens sur le couvain SMR en général pourraient expliquer le faible S.R. des acariens restants. D'autres expériences sont nécessaires pour déterminer l'action physiologique du couvain SMR sur le succès reproductif des acariens et savoir si les caractères HYG et SMR sont régulés par les mêmes gènes.

Apis mellifera / Varroa destructor / comportement hygiénique / reproduction des acariens / suppression

Zusammenfassung - Wirkungsweisen von Hygiene Verhalten und Unterdrückung der Milbenvermehrung beim Resistenzmechanismus der Honigbiene (Apis mellifera) gegen Varroa destructor. Wir untersuchten den Mechanismus durch den für den Faktor „Unterdrückung der Milben Reproduktion“" (SMR) gezüchtete Bienen den Vermehrungserfolg von Varroa destructor negativ beeinflussen. Wir untersuchten die Hypothese, dass SMR-Bienen mit vermehrungsfähigen Milben befallene Puppen erkennen und entfernen und damit den Eindruck erwecken, dass die Puppen einen reproduktionshemmenden Faktor besitzen, da die übriggebliebenen Milben ohne Nachkommen wären. Als Maßsystem für reproduktiven Erfolg untersuchten wir die Milbenfruchtbarkeit und Anzahl von lebensfähigen weiblichen Nachkommen. Wir untersuchten weiterhin, ob es einen physiologischen Faktor gibt, der bei SMR Arbeiterinnenbrut den reproduktiven Erfolg beeinträchtigt. Wir verglichen SMR Völker von Harbo mit Völkern der Zuchtlinien „Hygiene Verhalten“ (HYG) von der Universität von Minnesota. Zunächst untersuchten wir, ob SMR-Bienen Milben auf befallenen Puppen erkennen und entfernen können. Milben von 
SMR und HYG Völkern wurden in gerade verdekkelte Brutwaben von SMR and HYG Arbeiterinnenzellen eingesetzt und in SMR bzw. HYG Völker gegeben. Zehn Tage nach dem Milbeneinsatz hatten die 3 SMR Völker signifikant mehr befallenen Puppen entfernt als die 3 HYG Völker, unabhängig vom Ursprung der Milben $(P<0,0001)$ (Abb. 1). Als zweites verglichen wir den Reproduktionserfolg der Milben auf den verbliebenen Puppen (Tab. I). Milben, die in den SMR Völkern verblieben, waren signifikant weniger fruchtbar (weniger Milben legten mindestens ein Ei) als Milben in den HYG Völkern $(P=0,014)$, auch hatten sie signifikant weniger lebensfähige junge Weibchen (definiert als Präsenz einer lebenden adulten Tochtermilbe und einem lebenden adulten Männchen auf einem Puppenstadium mit grauem Flügelansatz) als Milben in HYG Völkern $(P=0,030)$. Um die Wirkung von SMR Brut auf die Milbenvermehrung zu prüfen, hielten wir befallene Brut im Wärmeschrank bei Temperatur und Luftfeuchtigkeit wie im Volk (Tab. II). Die Milben waren auf SMR Brut signifikant weniger fruchtbar $(P=0,033)$ und hatten signifikant weniger lebensfähige weibliche Nachkommen $(P=0,026)$ als auf HYG Brut. Die Ergebnisse bestätigen, dass Bienen der SMR Linien mit Milben befallenen Puppen signifikant häufiger erkennen und entfernen als Bienen der HYG Linien. SMR Bienen scheinen Puppen mit sich besonders erfolgreich vermehrenden Milben nicht selektiv zu entfernen, sodass nicht, wie anfangs angenommen, nur Puppen mit wenig Nachkommen übrig bleiben würden. Der Versuch im Wärmeschrank zeigte, dass sich alle Milben auf der SMR Brut weniger erfolgreich vermehrten als die auf HYG Brut. Demnach könnte bei SMR Linien die Kombination aus Entfernung von einem hohen Prozentsatz von infizierten Puppen zusammen mit der niedrigen Reproduktionsrate der Milben auf SMR Brut die niedrige Reproduktionsrate der Milben dieser SMR Völker erklären. Zur Bestimmung der physiologische Wirkungsweise der SMR Brut auf die Vermehrungsrate der Milben und ob die Eigenschaften von HYG und SMR durch dieselben Gene reguliert werden, sind weitere Versuche erforderlich

Apis mellifera / Unterdrückung der Milbenreproduktion / hygienisches Verhalten / Varroa destructor

\section{REFERENCES}

Boecking O. (1992) Removal behavior of Apis mellifera colonies towards sealed brood cells infested with Varroa jacobsoni: techniques, extent and efficacy, Apidologie 23, 371-373.

Boecking O., Spivak M. (1999) Behavioral defenses of honey bees against Varroa jacobsoni Oud., Apidologie 30, 141-158.
Corrêa-Marques M.H., Medina L.S., Martin S.J., De Jong D. (2003) Comparing data on the reproduction of Varroa destructor, Genet. Mol. Res. 2, 1-6.

Delaplane K.S., Hood W.M. (1999) Economic threshold for Varroa jacobsoni Oud. in the southeastern USA, Apidologie 30, 383-395.

Donzé G., Herrmann M., Bachofen B., Guerin P.M. (1996) Effect of mating frequency and brood cell infestation rate on the reproductive success of the honey bee parasite Varroa jacobsoni, Ecol. Entomol. 21, 17-26

Gilliam M., Taber S., Richardson G. (1983) Hygienic behavior of honey bee in relation to chalkbrood disease, Apidologie 14, 29-39.

Gilliam M., Taber S., Lorenz B., Prest D. (1988) Factors affecting development of chalkbrood diseases in colonies of honey bees, Apis mellifera, fed pollen contaminated with Ascosphaera apis, J. Invertebr. Pathol. 52, 314-325.

Harbo J.R., Harris J.W. (1999) Selecting honey bees for resistance to Varroa jacobsoni, Apidologie 30, 183-196.

Harbo J.R., Harris J.W. (2005) Suppressed mite reproduction linked to the behavior of adult bees, J. Apic. Res. 44, 21-23.

Harbo J.R., Hoopingarner R. (1997) Honey bee (Hymenoptera: Apidae) in the United States that express resistance to Varroa jacobsoni (Mesostigmata: Varroidae), J. Econ. Entomol. 90, 893-898.

Harris J.W., Harbo J.R. (1999) Low sperm counts and reduced fecundity of mites in colonies of honey bees (Hymenoptera; Apidae) resistant to Varroa jacobsoni (Mesostigmata: Varroidae), J. Econ. Entomol. 92, 83-88.

Ibrahim A., Spivak M. (2004) The relationship between suppression of mite reproduction (SMR) and hygienic behavior, Am. Bee J. 144, 406.

Kraus B., Velthuis H. (1997) High humidity in the honey bee (Apis mellifera L) brood nest limits reproduction of the parasitic mite Varroa jacobsoni Oud., Naturwissenschaften 84, 217-218.

Le Conte Y., Arnold G., Desenfant P.H. (1990) Influence of brood temperature and hybrometry variations on the development of the honey bee ectoparasite Varroa jacobsoni (Mesostigmata: Varroidae), J. Econ. Entomol. 19, 1780-1785.

Macedo P., Ellis M. (2002) Using inert dusts to detect and access Varroa infestation in honey bee colonies, J. Apic. Res. 40, 3-7.

Martin S.J. (1994) Ontogenesis of the mite Varroa jacobsoni Oud. in worker brood of honeybee Apis mellifera L. under natural conditions, Exp. Appl. Acarol. 18, 78-100.

Masterman R., Ross R., Mesce K., Spivak M. (2001) Olfactory and behavioral response thresholds to odors of diseased brood differ between hygienic and non-hygienic honey bees (Apis mellifera L.), J. Comp. Physiol. A 187, 441-452. 
McCulloch C., Searle S. (2002) Generalized, Linear and Mixed Models, Wiley, New York.

Medina L.M., Martin S.L. (1999) A comparative study of Varroa jacobsoni reproduction in worker cells of honey bees (Apis mellifera) in England and Africanized bees in Yucatan, Mexico, Exp. Appl. Acarol. 23, 659-667.

Milani N. (1999) The resistance of Varroa jacobsoni Oud. to acaridices, Apidologie 30, 229-234.

Mondragón L., Spivak M., Vandame R. (2005) A multifactorial study of the resistance of Africanized and hybrid honeybee Apis mellifera to the mite Varroa destructor over one year in Mexico, Apidologie 36, 345-358.

Park O.W. (1937) Testing for resistance to American foulbrood in honey bees, J. Econ. Entomol. 30, 504-512.

Rothenbuhler W.C. (1964) Behavior genetics of nest cleaning in honey bees. IV. Responses of F1 and backcross generations to disease-killed brood, Am. Zool. 4, 111-123.

Spivak M. (1996) Honey bee hygienic behavior and defense against Varroa jacobsoni, Apidologie 27, 245-260.

Spivak M., Downey D.L. (1998) Field assays for hygienic behavior in honey bees (Apidae: Hymenoptera), J. Econ. Entomol. 91, 64-70.
Spivak M., Gilliam M. (1993) Facultative expression of hygienic behavior of honey bees in relation to diseases resistance, J. Apic. Res. 32, 147-157.

Spivak M., Gilliam M. (1998) Hygienic behavior of honey bees and its application for control of brood diseases and varroa, Bee World 79, 169-186.

Spivak M., Reuter G.S. (1998a) Performance of hygienic honey bee colonies in a commercial apiary, Apidologie 29, 291-302.

Spivak M., Reuter G.S. (1998b) Honey bee hygienic behavior, Am. Bee J. 138, 283-286.

Spivak M., Reuter G.S. (2001a) Resistance to American foulbrood diseases by honey bee colonies Apis mellifera bred for hygienic behavior, Apidologie $32,555-565$.

Spivak M., Reuter G.S. (2001b) Varroa destructor infestation in untreated honey bee (Hymenoptera: Apidae) colonies selected for hygienic behavior, J. Econ. Entomol. 94, 326-331.

Spivak M., Masterman R., Ross R., Mesce K.A. (2003) Hygienic behavior in the honey bee (Apis mellifera L.) and the modulatory role of octopamine, $\mathrm{J}$. Neurobiol. 55, 341-354.

Woodrow A.W., Holst E.C. (1942) The mechanisms of colony resistance to American foulbrood, J. Econ. Entomol. 35, 327-330. 